\section{The Determinant Factors of Earnings Persistence}

Mia Oktavia ${ }^{1}$, Yulius Kurnia Susanto ${ }^{2}$

${ }^{1}$ Accounting Department, Trisakti School of Management, Jakarta, Indonesia

${ }^{2}$ Accounting Department, Trisakti School of Management, Jakarta, Indonesia

Email:

Abstract: The purpose of this research is to provide empirical evidence about the effect of operating cash flow, sales volatility, cash flow volatility, operating cycle, and book tax difference on earnings persistence. The company used in this research is manufacturing company listed in Indonesia Stock Exchange (IDX) from 2016 until 2020. Samples of this research were selected based on the purposive sampling method and resulted in 43 companies, therefore the data used for this research amounting to 215 data. The data obtained from these samples were analyzed using multiple regression method. The result of this research show that operating cycle have influence on earnings persistence. While operating cash flow, sales volatility, cash flow volatility, and book tax difference have no influence on earnings persistence.

Keywords: Earnings Persistence; Operating Cash Flow; Sales Volatility; Cash Flow Volatility; Operating Cycle; Book Tax Difference
Article History:

Received on 6 Jan 2022

Revised on 7 Jan 2022

Accepted on 10 Jan 2022

Doi: 10.37479

Indexing:

Google Scholar; Asean

Citation

Index; Copernicus; SINTA

5 (Science And

Technology Index)

The journal allows the authors to hold the copyright without restrictions and allow the authors to retain publishing rights without restrictions. international license.

\title{
INTRODUCTION
}

The pressure of global economic condition and globalization era has forced the firms to survive in keeping the performance and trying to always have a stability in their business. To face this conditions, the company must have adequate capital and sufficient funds. The firm will obtain more capital or funds, if company obtain the trust from creditors or investors. If the firm are able to show a good financial performance, they will get the trust. This occur because the investors or creditors will evaluate and predict the company performance based on the financial statement. One of the instrument that can measure the operational performance and management is earnings in financial statement that obtain by the firm every year. IAI (2015) stated that the structured presentation of company financial performance, the stream of cash, and financial position could be seen in the financial statement. Then, the information is also expected to be useful for financial statement users in making economic decision. Therefore, the component of earnings in financial statement should have a quality, because the earnings is the center of attention for financial users, like investors, creditors, government, and accounting policy maker. It is also important to assess because the earnings contain a predictive value in which earnings is use to predict future earnings.

A good financial analysis identifies components in earnings that exhibit stability and predictability that is, persistent components (Subramanyam \& Wild, 2014). Earnings information contain in the financial statement have an important role in assessing overall company performance. Earnings persistence involve in the overall performance of the company which is reflected in the company's profits. This viewpoint of earnings are persistent means the greater persistence will be reflected in the profit which can be continuous or sustainable for a long period (Fanani, 2010). Earnings persistence is defined as the durability and continuity of the current earnings. Greater persistence is also associated with a more sustainable operation flows. Therefore, if earnings are persistent, then investors need not be concerned about the extent of company current period's earnings will continue. The objective of a firm is to obtain the persistence of earnings, which means the earnings is always higher than previous earnings. The persistence of earnings become important, because it will determine the 
financial statement users like investors to analyze whether they want to invest or not. It also important for management who makes the decision.

However, there are companies failed to perform the persistence of earnings. In an instant, the company can obtain an increase in profit and also can suffer a decrease in profit. Besides, there are some companies still have a negative earnings. Negative earnings in the current year will not reflect the future earnings, which means the earnings does not look persistent. There are some cases in Indonesia regarding company fail in performing the persistence of earnings. According to Qolbi (2020) in investasi.kontan.co.id article that was reported on March 18th, 2020, PT Semen Indonesia Tbk (SMGR). One of the company which engaged in cement industry recorded sales Rp30,68 trillion in 2018 to Rp40,37 trilion. But, 22,31\% of earnings decreased from Rp3,08 trillion in 2018 to Rp2,39 trillion in 2019. The case from PT Fajar Surya Wisesa Tbk (FASW) in Indonesia recorded the decreasing amount of sales from Rp9,94 trillion in 2018 to Rp8,27 trillion in 2019. This company also recorded 31,06\% decreasing of earnings from Rp1,4 trillion in 2018 to Rp968,83 billion in 2019. Another example regarding an instantly big decrease in earnings and does not imply the earnings persistence comes from PT Astra Otoparts Tbk (AUTO). Quoted by Nurhaliza (2021) in idxchannel.com article that was reported on February 25th, 2021, the company has booked a profit attributable to owners of the parent of Rp739,67 billion in 2019, then suffered a dramatic fall by $99,7 \%$ in 2020 when it booked a profit attributable to owners of the parent of Rp2,24 billion. The decreasing of profit suspected because of the decreasing of sales from Rp15,44 trillion in 2019 to Rp11,86 trillion in 2020.

The three companies mentioned above are manufacturing companies in Indonesia. Darmono (2019) in suarakarya.id article that was reported on January 8th, 2019 stated the manufacturing company have an important role for the acceleration of national economic growth. Industrial sector in Indonesia contribute $20 \%$ for Gross Domestic Product (GDP), 30\% for taxation and 74\% for export. There are five sectors of manufacturing company that give a large contribution to Gross Domestic Product (GDP), taxation, and export, such as food and beverage industry, textile and clothing industry, automotive industry, chemical industry, and electronics industry.

Based on the case above, it seems hard for company to maintain the persistency of earnings. Some company still suffer loss for the year or low profit for the year, in which the contrast of the earnings from current period is too far from previous period. Therefore, the goal of this research is to examine the factors that influence the earnings persistence especially in manufacturing companies because the case also show the importance of manufacturing sectors for increasing the Indonesia's economic.

This research is the development of the previous research that has been done by Yanti (2017) with the determinant factors of earnings persistence are leverage, operating cash flow, and sales volatility. The similarity with previous research from Yanti (2017) are: (1) This research use all the independent variables from previous research by Yanti (2017); (2) The research is done in the same country that is Indonesia; and (3) The data of this research are obtained from manufacturing companies listed in Indonesia Stock Exchange (IDX) which can be access in www.idx.co.id. The difference between research conducted by Yanti (2017) and this research are: (1) This research period is taken from 2016 to 2020 (five years period observation), whereas the previous research used data from 2013 to 2015; (2) This research adds some additional independent variables that is cash flow volatility and operating cycle as independent variables which refer to the research conducted by Douglas et al. (2020); and (3) This research adds book tax difference and independent commissioner as independent variables which refer to the research conducted by Yulia et al. (2018). Based on research problems above, this research intends to examine and get empirical evidence about the influence of operating cash flow, sales volatility, cash flow volatility, operating cycle, and book tax difference on earnings persistence.

\section{Signaling Theory}

Signaling theory is the theory that proposed by Spence (1973). He proposed to solve the asymmetry information problem by giving a signal that could disclose some relevant information to other parties. Signaling theory is talking about the act of manager that use the accounts in financial statement to give an expectations and intentions signal regarding the future. The managers as the administrator of the company are tend to have more internal information about the prospect of the company rather than the owners. When the managers expected a high level of future growth by the firm, they would try to signal that to investors via the accounts. This signal is also to reduce asymmetry information or imbalance information to the financial statement users. Therefore, in this theory, the managers require to give a signal about the company condition in the form financial statement (Godfrey et al., 2010). Signaling theory is one of the theories about how managers are voluntarily giving the information to investors as a signal for investment decision making (Nurhaiyani, 2019).

Signaling theory predict the company will report the information more open and natural about company earnings and conditions (Soly \& Wijaya, 2018). Signaling theory states that all the earnings information that comes from the company can be a good signal for the external parties (Holly, 2019). The external parties can get the prediction about whether the company earnings are persistent. Company that has positive cash flow volatility and the positive earnings that have recurred in previous years will give a positive signal. Then, the external parties can consider their investment and trust the company. Company that has good creditworthiness will also give a positive signal about the earnings persistence. Company with low book tax differences also could give positive signal form the company earnings because it means that the manager has acted appropriately in performing the financial statement. The company have incentives to signal among good, neutral, or bad news (Godfrey et al., 2010). For example, the good news can be the increasing of earnings from the previous year. 
Meanwhile, bad news can be the decreasing of earnings from the previous year. About the neutral news, the earnings is similar with the previous year. Earnings persistence is one of the signals that investors need to make the decision for their investment, because the earnings persistence gives information about the sustainability of business. Then, the earnings persistence could attract the investors to invest in the company. In the other hand, when the earnings of the company are not persistent, the investors assume that company could not maintain its sustainability (Douglas et al., 2020).

\section{Earnings Persistence}

Earnings persistence refers to the revision of current earnings because the ability of the earnings persistence is showing the extent of future earnings and its sustainable for a long-term period (Pratomo \& Nuraulia, 2021). Earnings consist of two groups (Penman \& Zhang, 2002). The first group is sustainable earnings and the second group is unusual earnings. Sustainable earnings refer to core earnings or earnings persistence, which is the earnings that have the ability as the indicator for future earnings that generated by the company repetitively in long term period. While the unusual earnings or transitory earnings is the earnings that generated temporary and non-repetitive. Company that has earnings persistence also means that company have high quality of earnings. Therefore, earnings persistence is one of the indicators to assess the quality of company's profit. The earnings persistence tends not to fluctuate and reflect the sustainability of the future profit and continuously (Dewi \& Putri, 2015). When company earnings are persistent, it means it can be used as the indicator that a company has been successful in performing its business in certain period of time. While when the earnings of a company are not persistent or fluctuate and uncontrollably, it indicates that company unable to maintain the sustainability performance for the long-term period (Douglas et al., 2020).

There are some characteristics of the earnings persistence. The first is earnings persistence sign the enduring nature of an accounting earnings number. The second, the measurement of earnings persistence is the extent of current earnings can be recurred and persist in the future. Third, earnings persistence is the most desirable characteristic of earnings because it is indicative of sustainable earnings (Canina \& Potter, 2019). Therefore, earnings persistence has an important role in valuing the company earnings.

\section{Operating Cash Flow and Earnings Persistence}

Cash flow is the information about the changes of the cash in a company which is used by financial statement users in assessing the ability of the company to generating cash and cash equivalent and also the needs of the company to use its cash (IAI, 2015). Operating cash flow is the activities in cash flow that comes from main revenue. It shows the expenditures and the receipts of cash in the company. Besides, total operating cash flow also determine whether the company operation is enough or not for paying the debt and paying the cost related to the company operation without relying external funding sources (Andreas, 2017). Operating cash flows is the determination of earnings in the form of cash generated and issued by the company. Operating cash flow reduce asymmetry information because it gives a positive signal given by manager for external parties. The information from operating cash flow and the income from company operation will help both investor and creditor in making the decision and help to reduce the risk (Widiatmoko \& Indarti, 2019). The cash effects of revenue and expense transactions that generated by the company in cash flows from operating activities are the determination of net income (Kieso et al., 2018).

Operating cash flow is one of the factors that determine earnings persistence. Positive cash flow from operating activities indicates the company earnings look persistence. The confidence of creditors and investors in expecting the future earnings will increase when they know that the company has positive cash flow in operation activity (Yanti, 2017). Operating cash flow is called as a proxy for the earnings quality which the quality of earnings will be better as the operating cash flow increases (Dewi \& Putri, 2015).

Operating cash flow has a positive influence to earnings persistence (Aini \& Zuraida, 2020). The higher the operating cash flow, the higher the earnings persistence. If the indicator to predicting good performance is operating cash flow, it will relatively hard to be manipulated. The persistence of earnings could be affected by operating cash flow because a good performance of operating cash flow will reflect good earnings. Good earnings generated will be used by a company for operating activities without relying other funds from external parties. Based on signaling theory, if the company have higher earnings persistence and higher operating cash flow, it will indicate the successfulness of company in keeping the stability of earnings and also give a positive signal to market. This result is consistent with Barus and Rica (2014), Dewi and Putri (2015), Salsabiila et al. (2016), Putri et al. (2017), and Widiatmoko and Indarti (2019).

Meanwhile the research above not in line with Yanti (2017), operating cash flow has a negative effect to earnings persistence, which is if the operating cash flow increase, it can make lower earnings persistence. This possibly occurs because of the component of accruals in earnings are too high. Company with more accruals will has lower persistence of earnings compared to the company with lower accruals. Besides, the perspective of investors are earnings oriented. Hence, the investors might not realize that the good earnings are not always be accompanied by a strong positive operating cash flow.

Operating cash flow has no influence towards earnings persistence (Saputera et al., 2017). It because during the year observed, the company samples are likely more spend the cash rather than generate it and cannot do 
a company's operational well to obtain the earnings, particularly in maintaining and increasing the profit. This research is consistent with Maqfiroh and Kusmuriyanto (2018), Sarah et al. (2019), and Supriono (2021). Based on description above, the hypotheses is developed as follows:

$\mathrm{H}_{1}$ : Operating cash flow has influence on earnings persistence.

\section{Sales Volatility and Earnings Persistence}

Sales is one of the main components in generating the earnings. Good performance in the company can be illustrated by the high level of company sales, however it also based on each industry. The level of the sales that can be obtained by the company will determines the level of the company's earnings (Nadya \& Zultilisna, 2018). The volatility of sales means the movement of a sales are generated by the company that can be seen in some period. When the company sales decrease, it will give an impact to the earnings generated, because sales is the primary source. The higher the sales and demand of the products, it means the company have a wide market share (Ariyanti et al., 2021). According to Kusuma and Sadjiarto (2014), the information from sales is related with earnings of the company. High sales volatility in several periods must be questioned, because these things show there is a noise and problem in the sales information. In stable economic condition which is no economic crisis, the sales volatility should be low.

Sales volatility will show the quality of earnings in predicting the future earnings (Yanti, 2017). The higher the volatility of sales, the lower the persistence of earnings because the earnings that generated by the company contain a huge of noise. When sales volatility is high indicates sales information has bigger estimation error the operating environment, hence the company's earnings are not persistent and cannot act as a reference to predict future earnings (Fanani, 2010). The investors prefer company that have low volatility or relatively stable in sales, because the amounts of sales will reflect the company performance (Kasiono \& Fachrurrozie, 2016).

There is a positive effect between sales volatility towards earnings persistence (Nina et al., 2014). It means the higher the sales volatility, the higher the earnings persistence. It possibly occurs because the amount of revenues account in profit and loss statement are too small, rather than the other account like other revenues. Therefore, the small amount of sales is not disturbing the earnings persistence and it still can increase the persistency value. This result is consistent with Kasiono and Fachrurrozie (2016) Nadya and Zultilisna (2018), and Maharani and Majidah (2020).

There is a negative significant relationship between sales volatility to earnings persistence (Fanani, 2010). The higher the sales volatility, the lower the opportunity of the company to obtain earnings persistence in the future. This possibly occurs because of accounting noise that contain in the earnings generated by the company. This accounting noise means the distortions that occurred in financial statement due to lack of following accounting regulations and rules. The other reason, if the company have higher significant movement in some periods, it can be indicated that there is estimation error in revenue accounts and it shows that the revenue is not reflect the real amount. Therefore, the higher sales volatility influences the earnings persistence become lower. This result is consistent with Kusuma and Sadjiarto (2014), Rahmadhani et al. (2016), Amaliyah and Suwarti (2017), and Nahak et al. (2021).

There is no effect between sales volatility to earnings persistence (Ariyanti et al., 2021). It is because of the sales volatility is also affected by the macroeconomic condition. One of the conditions is trade war between Tiongkok and United Sates that give impacts to the global economic. Besides that, Indonesia was faced in a general election of legislative and president. Hence, most of the firm act is wait and see. Wait and see means the firms tend to be careful by delaying business expansion and investment and choose to wait until the economic condition are getting better. In other hand, the volatility happens because the needs of public increases along with increases of population in a country. Therefore, many factors affecting the sales volatility and it make the fluctuation of sales are not really give huge impact to the earnings persistence. These researches are in line with Yanti (2017), Saptiani and Fakhroni (2020), and Tuffahati et al. (2020). Based on description above, the hypotheses is developed as follows:

$\mathrm{H}_{2}$ : Sales volatility has influence on earnings persistence.

\section{Cash Flow Volatility and Earnings Persistence}

Statement of cash flow is the financial statement that provide information of operating, investing, and financing activities in cash basis about cash receipt and disbursement (Kieso et al., 2018). Investors use cash flow as a source information in making decision besides of earnings information (Fanani, 2010). Cash flow data is a good financial indicator because cash flow relatively is more difficult to be manipulated. Accounting manipulation usually do by using the different accounting method to make earnings look good.

The company with positive operating cash flow and not volatile will be trusted by investor for generating income. Low cash flow volatility is the indicator of stable earnings in the company. While, high cash flows volatility will show that there is uncertainty in operating and also in predicting future cash flow. The company that has higher persistence in earnings will show the lower volatility in cash flows. Based on agency theory stated that manager/agent have a contract with shareholders/principals related with processing function. In order to make 
the shareholders/principal satisfy, company's management will make an effort to obtain a more stable cash by showing the good performance. Based on signaling theory, the information in financial statement that made by company's management will give a signal to financial statement users. The stability of cash flow is positive signal information for company's earnings persistence (Holly, 2019).

To measure earnings persistence, need a stable cash flow information that is lower volatility of cash flow. If volatility of cash flow is high, it will be difficult to predict future cash flow. Therefore, high volatility will show the lower earnings persistence (Fanani, 2010). In business activity, the cash flow will show different number in each period. However, the number is not may be far apart in a short period. Therefore, when cash flow in a company's operations change drastically and continuously in a short period of time, then it will indicate that the cash flow is not reflect the real operational conditions. It means company's earnings also do not show the real situation and cannot be used as a basis for predicting the future earnings. The high volatility of cash flow can indicate that there is a high uncertainty in company's operational (Kusuma \& Sadjiarto, 2014).

Cash flow volatility has a positive effect on earnings persistence (Ariyanti et al., 2021). The higher cash flow volatility, the higher the earnings persistence. It occurs because the management of the company can manage the cash inflow and cash outflow properly. It includes managing the activities enter from sales of products or service and the activities of disbursement from payment of salaries expenses or another costs. Because of the effectivity and efficiency of managing cash flow, the earnings will be stable and persistent. This result also in line with Amaliyah and Suwarti (2017), Nadya and Zultilisna (2018), and Nahak et al. (2021).

There is a negative influence between cash flow volatility on earnings persistence (Holly, 2019). It means when the cash flow volatility is high, then the earnings persistence will become low. The reasons are because cash flow volatility is the fluctuation that generated by the company in certain period. High cash flows volatility will show that there is uncertainty in operating activity and also in predicting future cash flow. In other words, the higher cash flow volatility will make the uncertainty in obtaining the cash flow. This result is in line with Fanani (2010) and Maharani and Majidah (2020).

There is no effect between cash flow volatility to earnings persistence (Kasiono \& Fachrurrozie, 2016). It shows that cash flow volatility is not the accurate variable to estimate the earnings persistence. The investors are not using cash flow volatility to predict the earnings. This result is consistent with Hastutiningtyas and Wuryani (2019) and Susilo and Anggraeni (2015). Based on description above, the hypotheses is developed as follows:

$\mathrm{H}_{3}$ : Cash flow volatility has influence on earnings persistence.

\section{Operating Cycle and Earnings Persistence}

Operating cycle refers to the process of purchasing until collecting the cash that generated from sale of goods or service (Subramanyam \& Wild, 2014). In other words, operating cycle is the time period in which company change the cash into the asset in a short-term period and back again into cash as the part of operating activity. When it is manufacturing company, the cycle begins from buying raw materials and converting them to finished goods, then selling the goods to generate cash or receivables. According to Fanani (2010), Operating cycle is an average time period between purchasing the inventory and cash received by company or whole series transactions hat a business generates cash receipt from customer. There are factors that influence the operating cycle which are inventories, accounts receivables, sales, and cost of goods sold in which that this component related with cash period (Fauzia \& Sukarmanto, 2016).

Operating cycle is related with company earnings, because the earnings will be used as predicting tool for future cash flow (Amaliyah \& Suwarti, 2017). Therefore, earnings that used as a predicting tool must have a quality and the quality of earnings rely on company operating cycle. From the cash disbursement to purchase inventory until cash receipt from sales could be considered as cash in current period that can reflecting the earnings in future periods. Short operating cycle will make the earnings in previous period reflecting the earnings for next period (Fauzia \& Sukarmanto, 2016). Company that has longer operating cycle can raise uncertainty and large estimation error, so that this can make earning persistence value become lower (Fanani 2010).

Operating cycle has a negative effect to earnings persistence (Douglas et al., 2020). It means the shorter the operating cycle, the higher the earnings persistence. It because operating cycle in company tend to be fast, therefore the time period from the spending cash for buying inventories until generating cash from sales is quite short. The cash receipt from sales is the cash profit in current period that can reflect the next period earnings. The shorter the time for collecting cash, the higher the earnings persistence.

In other hand, the result from Lee et al. (2018), Amaliyah and Suwarti (2017), Fauzia and Sukarmanto (2016), the result shows that operating cycle has a positive effect to earnings persistence. It means the longer the operating cycle, the higher the earnings persistence. It occurs because of when the time for collecting cash is longer, the financial statement will reflect the real earnings, and therefore it can make the higher quality of earnings. The earnings generated will be high with assumption if the expenses are not higher than the revenues. Therefore, because the quality of earnings is not containing too much noise of accrual, the earnings persistence could be higher. 
Meanwhile, in Sarah et al. (2019) stated that there is no effect between operating cycle to earnings persistence. It occurs because the shorter or longer operating cycle does not affect to the capital work and the realization of cash. So that, the company performance is not affected too. Long operating cycle will not make higher uncertainty of realizing the cash. Therefore, it is not affecting to determine future cash flow. Therefore, the shorter or longer operating cycle will not give impact to the increasing or decreasing of earnings persistence. This result also in line with Fanani (2010), Susilo and Anggraeni (2015), and Lasrya and Ningsih (2020). Based on description above, the hypotheses is developed as follows:

$\mathrm{H}_{4}$ : Operating cycle has influence on earnings persistence.

\section{Book Tax Difference and Earnings Persistence}

Book tax difference is the gap between accounting earnings and fiscal earnings. The gap occurs because there is a different goal between accounting standard rules and tax rules (Dewi \& Putri, 2015). Commercial/accounting financial reports and fiscal financial report have a different goal. Commercial financial reports are used for assessing economic performance and circumstances finance from the business sector, while fiscal financial reports are aimed more to calculate tax. The gap also occurs because not all the accounting rules in financial accounting standards is allowed for tax rules (Barus \& Rica, 2014). The difference between commercial and fiscal earnings consist of two, first is permanent differences and the second is temporary/timing differences. The permanent differences occur because of rules regarding the revenues and expenses recognition between accounting standard and the tax rules. The temporary differences occur as an impact from the differences in recognition time over revenues and expenses according to the accounting standards with laws conditions and tax rules. (Bas et al. 2020).

In this research, the book tax difference variable refers to the temporary difference, which is disclosed as a deferred tax in financial statement. Deferred tax is a tax expense or deferred tax expense that can have an effect such as increasing or decreasing the tax burden that must be paid in the future. According to IAI (2014), when commercial earnings are greater than fiscal earnings, the tax difference will be recognized as a deferred tax expense and deferred tax liability. However, when commercial earnings are smaller than fiscal earnings, the tax difference should be recognized as a deferred tax benefit and deferred tax asset. Because of the deferred tax from temporary difference will cause the increasing or decreasing for profit after tax, thus it will affect earnings persistence (Putri et al. 2017).

Based on research from Dewi and Putri (2015), book tax difference has a positive influence on earnings persistence. It means the larger amount of book tax difference, the higher the earnings persistence. The composition of deferred tax expenses tend not too large, therefore it cause the earnings movement tend not to not far apart in each transition period. Thus, it will make the earnings become more persistent. Meanwhile, the research from Widiatmoko and Indarti (2019) stated that the higher the book tax differences, the lower the earnings persistence. It possibly occurs because the amount of deferred tax liability will impact to deferred tax expense. If the temporary difference amount caused by deferred tax liability is large, it indicates the company should pay more for deferred tax expense. Then, it will give the impact to the earnings which is the earnings become lower and less persistent.

There is no influence between book tax differences which is proxies by temporary difference on earnings persistence (Bashri et al., 2020). It occurs because the deferred tax size that owned by company does not affect the earnings generated in the next period or earnings prediction. The other reason is that temporary difference occurs due to rules in accounting and tax regulations in which this is depends on the large amount of the differences. Therefore, if the amount of difference is not too large, it will not affect the earnings persistence. This result is also consistent with Barus and Rica (2014), Prasetyo and Rafitaningsih (2015), Putri et al. (2017), Holly (2019), Maulita and Framita (2021). Based on description above, the hypotheses is developed as follows:

$\mathrm{H}_{5}$ : Book tax difference has influence on earnings persistence.

\section{METHODOLOGY}

The population used by this research is all the manufacturing companies listed on Indonesia Stock Exchange for observation period of 2016 to 2020 . The research data is obtained from company financial statement. The sample result is 43 manufacturing company with five period observed, thus the total data used for this research are 215 data. The sampling criteria and procedure are summarized as follows:

Table 1. Sample Selection Procedure

\begin{tabular}{lcc}
\hline \multicolumn{1}{c}{ Criteria Description } & Total Companies & $\begin{array}{c}\text { Total } \\
\text { Data }\end{array}$ \\
\hline $\begin{array}{l}\text { Consistently manufacturing companies listed in Indonesia } \\
\text { Stock Exchange (IDX) from 2012 to 2020 }\end{array}$ & 124 & 620 \\
$\begin{array}{l}\text { Audited financial statements do not end as of } \\
\text { December 31st from 2012 to 2020 }\end{array}$ & (4) & $(20)$ \\
\hline
\end{tabular}




\begin{tabular}{|c|c|c|}
\hline $\begin{array}{l}\text { Company that are not used Rupiah's currency in its } \\
\text { reported financial statement from } 2012 \text { to } 2020\end{array}$ & $(25)$ & $(125)$ \\
\hline $\begin{array}{l}\text { Company that are not generate profit after tax from } 2012 \\
\text { to } 2020\end{array}$ & $(49)$ & $(245)$ \\
\hline $\begin{array}{l}\text { Company that has not provide complete data needed for } \\
\text { the research }\end{array}$ & (3) & $(15)$ \\
\hline Number of chosen samples & 43 & 215 \\
\hline
\end{tabular}

Earnings persistence is calculated with the linear regression analysis of the current earnings with the previous earnings during five years, as used by Nuraeni et al. (2018). Earnings persistence variable is measured by calculating the after-tax earnings regression according to Douglas et al. (2020), as follow:

$E_{i t}=\beta_{0}+\beta_{1} E_{i t-1}+\varepsilon$

Where:

Eit $\quad=$ Profit after tax company $\mathrm{i}$ in period $\mathrm{t}$

$\beta_{0} \quad=$ Constant variable

$\beta_{1} \quad=$ Earnings persistence

$\mathrm{E}_{\mathrm{it}-1} \quad=$ Profit after tax company $\mathrm{i}$ before period $\mathrm{t}$

$\varepsilon \quad=$ Error

\section{Independent Variable}

Operating cash flow is the stream of cash that generated by the company operating activity. Cash is the important part of a company in order to keep the company sustainability (Sarah et al. 2019). The parameter to calculate operating cash flow is only based on total operating cash flow in the current year (Yanti, 2017). Sales volatility indicates the earnings information. The size of sales that generated by company will determine the company earnings (Nadya \& Zultilisna, 2018). The value of sales volatility is measured from the standard deviation of five years' sales divided total assets (Fanani, 2010). Statement of cash flow provide information of operating, investing, and financing activities in cash basis about cash receipt and expenditure (Kieso et al., 2018). The value of cash flow volatility is measured from the standard deviation of five years' operating cash flow divided total assets (Fanani, 2010; Douglas et al., 2020). Operating cycle is the part of cycle that directly involve to the company earnings and it occurs continuously. The operating cycle is measured by adding the average of inventory and accounts receivable. The measurement of operating cycle is adapted from Douglas et al. (2020) as follows:

$$
O C=\left(\left(A_{t}+A R_{t-1}\right) / 2\right) /\left(\text { Salest }_{t} / 360\right)+\left(\left(\text { Inven }_{t}+\text { Inven }_{t-1}\right) / 2\right) /\left(\text { COGS }_{t} / 360\right)
$$

$$
\begin{array}{ll}
\mathrm{OC} & =\text { Operating Cycle } \\
\left(\mathrm{AR}_{\mathrm{t}}+\mathrm{AR} \mathrm{R}_{\mathrm{t}-1}\right) & =\text { Average of accounts receivables of company } \mathrm{i} \text { year } \mathrm{t} \\
\text { Sales }_{\mathrm{z}} & =\text { Sales } \\
\text { IInven } \left._{t}+\text { Inven }_{\mathrm{t}-1}\right) & =\text { Average of inventory of company } \mathrm{i} \text { year } \mathrm{t} \\
\text { COGS }_{\mathrm{t}} & =\text { Cost of Goods Sold }
\end{array}
$$

Book tax difference mean there is a gap between the earnings based on accounting standard and tax regulation and the gap will cause the changes of increasing or decreasing in future company earnings (Rahmadhani et al., 2016). The measurement of book tax difference will focus on temporary difference which is disclosed in the amount of deferred tax expense (benefit) divided prior total assets (Bashri et al., 2020).

\section{Control Variable}

Leverage is the ratio to measure the level of debt by comparing the total liabilities with the total assets (Yanti, 2017). The size of a company can consist of three categories, which is large firm, medium size firm, and small firm. The high growth of earnings is very expected for large size of the company (Septavita, 2016). The measurement of firm size is natural logarithm of total asset (Rajizadeh \& Rajizadeh, 2013). Independent commissioner is the total board commissioner from the outside of the company (Khafid, 2012). Independent commissioner is the party that give an oversight to the firm's management in order to achieve the goal of the company which is to have earnings persistence (Pernamasari, 2018).

This research uses multiple regression analysis in order to test the data. The multiple regression equation in this research is written as follow:

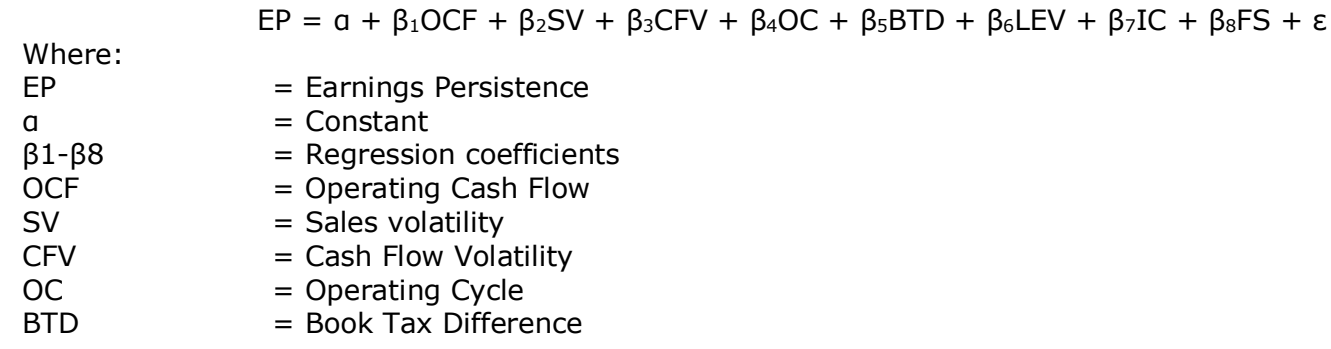




$\begin{array}{ll}\text { LEV } & =\text { Leverage } \\ \text { IC } & =\text { Independent Commissioner } \\ \text { FS } & =\text { Firm size } \\ \varepsilon & =\text { error }\end{array}$

\section{RESULTS}

Table 2 show the result of descriptive statistic test with interpretation and description about the characteristics of 215 observed data:

Table 2. Descriptive Statistics Result

\begin{tabular}{lcrrrr}
\hline Variable & N & Minimum & Maximum & Mean & Std. Deviation \\
\hline EP & 215 & $-11,782110$ & 5,069445 & 0,35084068 & 1,361090188 \\
OCF & 215 & $-1.85 \mathrm{E}+12$ & $3.77 \mathrm{E}+12$ & $2.34 \mathrm{E}+12$ & $5.14 \mathrm{E}+12$ \\
SV & 215 & 0,025610 & 0,838093 & 0,15038651 & 0,100937645 \\
CFV & 215 & 0,009494 & 0,175923 & 0,05025103 & 0,029639919 \\
OC & 215 & 51,607782 & 493,692811 & 151,24983823 & 69,837880190 \\
BTD & 215 & $-0,025999$ & 0,010860 & $-0,00095766$ & 0,005081091 \\
LEV & 215 & 0,092483 & 0,807311 & 0,37027245 & 0,174865085 \\
IC & 215 & 0,285714 & 0,833333 & 0,40700695 & 0,103446499 \\
FS & 215 & 25,795711 & 33,494533 & 28,97098666 & 1,742981584 \\
\hline
\end{tabular}

Source: Result of data processing (2021)

The Earnings Persistence (EP) variable has a minimum value of $-11,782110$ which is MERK 2018 and maximum value of 5,069445 which is EKAD 2016. The mean value of earnings persistence is 0,35084068 and last for standard deviation value is 1,361090188 . The Operating Cash Flow (OCF) variable has a minimum value of 1.853.834.642.000 which is KAEF 2019 and a maximum value of 37.683.000.000.000 which is ASII 2020. The mean value of operating cash flow is $2.335 .879 .248 .097,19$ and last for the standard deviation value is 5.139.276.682.958,317. The Sales Volatility (SV) variable has a minimum value of 0,025610 which is SMGR 2017 and a maximum value of 0,838093 which is CEKA 2016. The mean value and standard deviation of sales volatility is 0,15038651 and 0,100937645 . The Cash Flow Volatility (CFV) variable has a minimum value of 0,009494 which is KAEF 2016 and a maximum value of 0,175923 which is MERK 2019. The mean value of cash flow volatility is 0,05025103 and last for the standard deviation value is 0,029639919 . The Operating Cycle (OC) variable has a minimum value of 51,607782 which is ROTI 2016 and a maximum value of 493,692811 which is DLTA 2020. The mean value and standard deviation of operating cycle is 151,24983823 and 69,837880190. The Book Tax Difference (BTD) variable has a minimum value of $-0,025999$ which is CEKA 2016 and a maximum value of 0,010860 which is ROTI 2016. The mean value of book tax difference is $-0,00095766$ and last for the standard deviation value is 0,005081091 .

The result of partial hypotheses test (t-test) can be seen in Table 3 below:

Tabel 3. T-Test Result

\begin{tabular}{crl}
\hline Variable & B & Sig. \\
\hline (Constant) & 0,504 & 0,842 \\
OCF & $-4,769$ & 0,859 \\
SV & 0,594 & 0,565 \\
CFV & $-4,153$ & 0,228 \\
OC & $-0,003$ & 0,033 \\
BTD & 10,624 & 0,563 \\
LEV & $-0,983$ & 0,079 \\
IC & 0,560 & 0,548 \\
FS & 0,021 & 0,803
\end{tabular}

Source: Result of data processing (2021)

The $t$ test shows that operating cash flow (OCF) has coefficient value (B) of $-4,769$ with 0,859 significant value. It can be concluded that operating cash flow has no influence on earnings persistence because the significance value is higher than 0,05 , therefore $\mathrm{H}_{1}$ is not supported.

The $t$ test shows that sales volatility (SV) has coefficient value (B) of 0,594 with 0,565 significant value. It can be concluded that sales volatility has no influence on earnings persistence because the significance value is higher than 0,05 , therefore $\mathrm{H}_{2}$ is not supported. 
The t test shows that cash flow volatility (CFV) has coefficient value (B) of $-4,153$ with 0,228 significant value. It can be concluded that cash flow volatility has no influence on earnings persistence because the significance value is higher than 0,05 , therefore $\mathrm{H}_{3}$ is not supported.

The $t$ test shows that operating cycle (OC) has coefficient value (B) of $-0,003$ with 0,033 significant value. As the significance value is lower than 0,05 , it can be concluded that operating cycle has influence on earnings persistence, therefore $\mathrm{H}_{4}$ is supported.

The $t$ test shows that book tax difference (BTD) has coefficient value (B) of 10,624 with 0,563 significant value. It can be concluded that book tax difference has no influence on earnings persistence because the significance value is higher than 0,05 , therefore $\mathrm{H}_{5}$ is not supported.

\section{DISCUSSION}

Operating cash flow has no influence on earnings persistence. The data of this research shows that there are companies with negative cash flow. It leads to the condition that the earnings gained by the companies is still unable to cover the company activity so that the company needs to rely on external funding. Cash basis method used in operating cash flow is not showing accrual option on earnings with accrual method. It can be concluded that the amount of operating cash flow of the company has no influence on its earnings persistence. Operating cash flow in this study is unable to be the basis of decision making of the investor (Maqfiroh \& Kusmuriyanto, 2018). Operating cash flow does not make the company maintain the earnings as it can be shown in earnings persistence number and earnings persistence tends to decrease. It means the company main operation has no enough ability for paying the debt and paying the cost related to the company then it makes company still relying external funding sources. Another reason is because during the year observed, the company samples are likely more spend the cash rather than generate it and cannot do a company's operational well to obtain the earnings, particularly in maintaining and increasing earnings (Saputera et al., 2017).

Sales volatility has no influence on earnings persistence. It is because of the sales volatility is also affected by the macroeconomic condition. One of the conditions is trade war between Tiongkok and United Sates that give impacts to the global economic. Besides that, Indonesia was faced in a general election of legislative and president. Hence, most of the firm act is wait and see. Wait and see means the firms tend to be careful by delaying business expansion and investment and choose to wait until the economic condition are getting better. In other hand, the volatility happens because the needs of public increases along with increases of population in a country. Therefore, many factors affecting the sales volatility and its fluctuation of sales do not really give huge impact to the earnings persistence (Ariyanti et al., 2021).

Cash flow volatility has no influence on earnings persistence. It shows that operating cash flow in a company that has a drastic change in short term period continuously does not reflect the real condition so that it is hard to be used for predicting earnings in the next period. Volatility is not the accurate variable to estimate the earnings persistence. The investors are not using cash flow volatility to predict the earnings because of inability of cash flow volatility to predict the cash flow in the next year (Kasiono \& Fachrurrozie, 2016).

Operating cycle has influence on earnings persistence. The effect of operating cycle on earnings persistence is negative. When the operating cycle which is calculated by the time average of collection period and the average age of inventory is faster, it will increase the earnings persistence value of a company. This means the operating cycle is used by the investor as a source of information of the length of time used by the company to generating cash from the main operations, in accordance with signaling theory (Douglas et al., 2020).

Book tax difference has no influence on earnings persistence. It occurs because the deferred tax size that owned by company does not affect the earnings generated in the next period or earnings prediction. The other reason is that temporary difference occurs due to rules in accounting and tax regulations in which it depends on the large amount of the differences. Therefore, if the amount of difference is not too large, it will not affect the earnings persistence (Bashri et al., 2020).

\section{CONCLUSION}

The conclusions are operating cycle has influence on earnings persistence. However, leverage, operating cash flow, sales volatility, cash flow volatility, book tax difference, independent commissioner, and firm size has no influence on earnings persistence. There is some recommendation that could be considered for future researchers, which are: (1) The further research is expected to enlarge the samples of the research that are not limited only for manufacturing companies; and (2) The further research is expected to add more independent variables which variations might give more contribution in explaining the variation of earnings persistence, like magnitude of accruals, and market concentration.

\section{REFERENCES}

Aini, A.Q., \& Zuraida. (2020). Pengaruh Arus Kas Operasi, Tingkat Utang, dan Opini Audit Terhadap Persistensi Laba pada Perusahaan Pertambangan yang Terdaftar di BEI Periode 2013-2016. Jurnal Ilmiah Mahasiswa Ekonomi Akuntansi, 5(2), 182-192. https://doi.org/10.24815/jimeka.v5i2.15552. 
Amaliyah, K., \& Suwarti, T. (2017). Faktor-Faktor Penentu Persistensi Laba. Journal of Chemical Information and Modeling, 6(2), 176-188.

Andreas. (2017). International Journal of Economics and Financial Issues Analysis of Operating Cash Flow to Detect Real Activity Manipulation and Its Effect on Market Performance. International Journal of Economics and Financial Issues, 7(1), 524-29.

Ariyanti, D., Ermaya, H.N.L., \& Nugraheni, R. (2021). Determinasi Persistensi Laba pada Perusahaan di Indonesia. Konferensi Riset nasional Ekonomi, Manajemen, dan Akuntansi, 2, 1014-1032.

Barus, Andreani Caroline, \& Rica, V. (2014). Analisis Faktor-Faktor yang Mempengaruhi Persistensi Laba pada Perusahaan Manufaktur di Bursa Efek Indonesia. JWEM (Jurnal Wira Ekonomi Mikroskil), 4(2), 71-80.

Bashri, M., Pagalung, G., \& Indrijawati, A. (2020). The Effect of Book-Tax Diffferences, Cash Flow Volatility, and Corporate Governance on Earning Quality. International Journal of Innovative Science and Research Technology, 5(11), 367-376.

Canina, L., \& Potter, G. (2019). Determinants of Earnings Persistence and Predictability for Lodging Properties. Cornell Hospitality Quarterly, 60(1), 40-51. https://doi.org/10.1177/1938965518791729.

Dewi, N.P.L., \& Putri, I.G.A.M.A.D. (2015). Pengaruh Book-Tax Difference, Arus Kas Operasi, Arus Kas Akrual, dan Ukuran Perusahaan. Jurnal Akuntansi Universitas Udayana, 1(10), 244-260.

Douglas, Ulupui, I.G.K.A., \& Nasution, H. (2020). The Influence of Operating Cycle, Cash Flow Volatility, and Audit Fee on Earnings Persistence (The Indonesian Cases). Sriwijaya International Journal of Dynamic Economics and Business, 4(1), 1-20. https://doi.org/10.29259/sijdeb.v4i1.1-20.

Fanani, Z. (2010). Analisis Faktor-Faktor Penentu Persistensi Laba. Jurnal Akuntansi Dan Keuangan Indonesia, 7(1), 109-123. https://doi.org/10.21002/jaki.2010.06.

Fauzia, E., \& Sukarmanto, E. (2016). Pengaruh Keandalan Akrual Dan Siklus Operasi Terhadap Persistensi Laba Pada Perusahaan Retail Trade Yang Terdaftar Di Bursa Efek Indonesia. Journal of Accounting and Economics, 17(2). https://doi.org/10.29313/ka.v16i1.2612.

Godfrey, J., Hodgson, A., Tarca, A., Hamilton, J., \& Holmes, S. (2010). Accounting Theory, 7th Edition. Accounting Theory. Australia: John Willey and Sons.

Hastutiningtyas, P.D., \& Wuryani, E. (2019). Pengaruh Volatilitas Arus Kas Dan Kepemilikan Nabajerial Terhadap Persistensi Laba. Jurnal Akuntansi Unesa, 7(3).

Holly, A. (2019). Volatilitas Arus Kas, Tingkat Utang, Book Tax Differences Dan Dampaknya Terhadap Persistensi Laba. Atma Jaya Accounting Research, 2(2), 121-153. https://doi.org/10.35129/ajar.v2i02.84.

Ikatan Akuntan Indonesia. (2015). Laporan Arus Kas Menurut PSAK No.2. PSAK No.2.

Kasiono, D., \& Fachrurrozie. (2016). Determinan Persistensi Laba pada Perusahaan Manufaktur yang Terdaftar di BEI. Accounting Analysis Journal, 5(1), 1-8.

Khafid, M. (2012). Pengaruh Tata Kelola Perusahaan (Corporate Governance) Dan Struktur Kepemilikan Terhadap Persistensi Laba. Jurnal Dinamika Akuntansi, 4(2), 139-148.

Kieso, D.E., Weygandt, J.J., \& Warfield, T.D. (2018). Intermediate Accounting IFRS.

Kusuma, B., \& Sadjiarto, R. (2014). Analisa Pengaruh Volatilitas Arus Kas, Volatilitas Penjualan, Tingkat Hutang, Book Tax Gap, dan Tata Kelola Perusahaan terhadap Persistensi Laba. Tax and Accounting Review, 4(1).

Lasrya, E., \& Ningsih, O. (2020). Analisis Faktor Faktor Yang Mempengaruhi Persistensi Laba Pada Perusahaan Makanan dan Minuman yang Terdaftar di Bursa Efek Indonesia Periode 2013 - 2017. Research in Accounting Journal (RAJ), 1(1), 16-31.

Lee, R.M., Panjaitan, F., \& Hasibuan, R. (2018). Analisis Volatilitas Arus Kas, Tingkat Hutang dan Siklus Operasi terhadap Persistensi Laba (Studi Kasus Pada PT Timah (Persero) Tbk Pangkalpinang). Jurnal Ilmiah Akuntansi Bisnis \& Keuangan (JIABK), 13(1), 52-61. 
Maharani, N.A., \& Majidah. (2020). Persistensi Laba: Volatilitas Arus Kas, Volatilitas Penjualan dan Keandalan Akrual (Studi Empiris Pada Perusahaan Sektor Properti, Real Estate, dan Konstruksi Bangunan yang Terdaftar di Bursa Efek Indonesia Periode 2014-2018). E-Proceeding of Management, 7(2), 3315-3322.

Maqfiroh, C.S., \& Kusmuriyanto. (2018). The Influence of Book Tax Differences, Operating Cash Flow, Leverage, and Firm Size towards Earnings Persistence. Accounting Analysis Journal, 7(3), 151-158.

Maulita, D., \& Framita, D.S. (2021). Pengaruh Pajak Tangguhan Dan Ukuran Perusahaan Terhadap Persistensi Laba (The Effect of Deffered Tax and Company Size on Earnings Persistence). Jurnal Akuntansi, Kuangan, dan Manajemen (Jakman), 2(2), 141-152.

Nadya, N.F., \& Zultilisna, D. (2018). Analisis Faktor-faktor Penentu Persistensi Laba. Jurnal Akrab Juara, 2(3), 157-169.

Nahak, K.H.T., Ekayani, N.N.S., \& Riasning, N.P. (2021). Pengaruh Volatilitas Arus Kas, Volatilitas Penjualan, Tingkat Hutang dan Ukuran Perusahaan Terhadap Persistensi Laba pada Perusahaan Pertambangan Batu Bara yang Terdaftar di Bursa Efek Indonesia (BEI) Periode 2014-2018. Jurnal Riset Akuntansi Warmadewa, 2(2), 92-97. https://doi.org/10.22225/jraw.2.2.3360.92-97.

Nina, H.B., \& Arfan, M. (2014). Pengaruh Volatilitas Arus Kas, Volatilitas Penjualan, Besaran Akrual, Dan Financial Leverage Terhadap Persistensi Laba Pada Perusahaan Manufaktur Yang Terdaftar Di Bursa Efek Indonesia. Jurnal Akuntansi Program Pascasarjana Unsyiah, 3(2), 1-12.

Nuraeni, R., Mulyati, S., \& Putri, T.E. (2018). Faktor-Faktor Yang Mempengaruhi Persistensi Laba (Studi Kasus Pada Perusahaan Property dan Real Estate yang Terdaftar di Bursa Efek Indonesia Tahun 2013-2015). Accruals (Accounting Reserach Journal of Sutaatmadja), 1(1), 82-112. https://doi.org/10.35310/accruals.v2i1.8.

Nurhaliza, S. (2021). Laba Astra Otoparts Turun 23,18 Persen Sepanjang 2020. Idxchannel.com, 25 Febuari. https://www.idxchannel.com/market-news/laba-astra-otoparts-turun-2318-persen-sepanjang2020/(diakses 1 November 2021).

Nurhaiyani (2019). Pengaruh Corporate Governance, Leverage Dan Faktor Lainnya Terhadap Nilai Perusahaan Non-Keuangan. Jurnal Bisnis Dan Akuntansi, 20(2), 107-16. https://doi.org/10.34208/jba.v20i2.415.

Penman, S.H., \& Xiao Jun Zhang. (2002). Accounting Conservatism, the Quality of Earnings, and Stock Returns. Accounting Review, 77(2), 237-264. https://doi.org/10.2308/accr.2002.77.2.237.

Pernamasari, R. (2018). The Effect of Accrual earnings, COrporate Governance, and Firm Size on Earnings Persistence of 100 Compass Index Companies Listed in 2015-2016. Journal of economics and Sustainable Development, 9(10), 196-205.

Prasetyo, B.H., \& Rafitaningsih. (2015). Analisis Book Tax Differences Terhadap Persistensi Laba, Akrual dan Aliran Kas pada Perusahaan Jasa Telekomunikasi. JIAFE (Jurnal Ilmiah Akuntansi Fakultas Ekonomi), 1(1), 27-32. https://doi.org/10.34204/jiafe.v1i1.293.

Pratomo, D., \& Nuraulia, A.N. (2021). Pengaruh Kepemilikan Institusional, Kepemilikan Manajerial dan Konsentrasi Kepemilikan terhadap Persistensi Laba. Jurnal Bisnis dan Akuntansi, 23(1), 13-22.

Putri, S.A., Khairunnisa, A, \& Kurnia, M. (2017). Aliran Kas Operasi, Book Tax Differences, Dan Tingkat Hutang Terhadap Persistensi Laba. Jurnal Riset Akuntansi Kontemporer, 9(1), 29-38. https://doi.org/10.23969/jrak.v9i1.365.

Qolbi, N. (2020). Turun 43,53\% Sepanjang 2020, Begini Kinerja Tujuh Emiten Sektor Industri Dasar. Investasikontancoid, 18 Maret. https://investasi.kontan.co.id/news/turun-4353-sepanjang-2020-beginikinerja-tujuh-emiten-sektor-industri-dasar/(diakses 1 November 2021).

Rahmadhani, A., Zulbahridar, \& Hariadi. (2016). Pengaruh Book-Tax Differences, Volatilitas Arus Kas, Volatilitas Penjualan, Besaran Akrual, dan Tingkat Utang terhadap Persistensi Laba (Studi Empiris pada Perusahaan Aneka Industri yang Terdaftar di BEI Tahun 2010-2014). Jurnal Online Mahasiswa Fakultas Ekonomi Universitas Riau, 3(1), 2163-2176.

Rajizadeh, S., \& Rajizadeh, S. (2013). Examining the Factors Affecting Earnings Persistency among the Listed Firms in Tehran Stock Exchange. European Online Journal of Natural and Social Sciences, 2(3), 20732079. 
Salsabiila, A., Dudi, P., \& Annisa, N. (2016). Pengaruh Book Tax Differences Dan Aliran Kas Operasi Terhadap Persistensi Laba. Jurnal Akuntansi, 20(2), 314-329. https://doi.org/10.24912/ja.v20i2.61.

Saptiani, A.D., \& Fakhroni, Z. (2020). Pengaruh Volatilitas Penjualan, Volatilitas Arus Kas Operasi, dan Hutang terhadap Persistensi Laba. Jurnal ASET (Akuntansi Riset), 12(1), 201-211. https://doi.org/10.17509/jaset.v12i1.23570.

Saputera, E.N., Norita, \& Dillak, V.J. (2017). Pengaruh Book Tax Differences Dan Aliran Kas Operasi Terhadap Persistensi Laba. E-Proceeding of Management, 4(1), 523-532.

Sarah, V., Jibrail, A., \& Martadinata, S. (2019). Pengaruh Arus Kas Kegiatan Operasi, Siklus Operasi, Ukuran Perusahaan dan Tingkat Hutang terhadap Persistensi Laba (Studi Empiris pada Perusahaan Jasa Sub Sektor Konstruksi dan Bangunan yang Terdaftar di Bursa Efek Indonesia Periode 2013-2016). Jurnal TAMBORA, 3(1), 45-54. https://doi.org/10.36761/jt.v3i1.184.

Septavita, N. (2016). Pengaruh Book Tax Diferences, Arus Kas Operasi, Tingkat Hutang, dan Ukuran Perusahaan terhadap Persistensi Laba. Jurnal online mahasiswa Fakultas Ekonomi Universitas Riau, 3, (1), 1309-1323.

Soly, N., \& Wijaya, N. (2018). Faktor-Faktor Yang Mempengaruhi Kualitas Laba Pada Perusahaan Manufaktur. Jurnal Bisnis Dan Akuntansi, 19(1), 47-55. https://doi.org/10.34208/jba.v19i1.64.

Spence, M. (1973). Job Market Signaling. Quarterly Journal of Economics, 87(3), 355-374. https://doi.org/10.2307/1882010.

Subramanyam, K. R., \& Wild, J.J. (2014). Financial Statement Analysis Eleventh Edition. United States: McGraw-Hill Education.

Supriono. (2021). Pengaruh Arus Kas Operasi, Tingkat Hutang dan Ukuran Perusahaan terhadap Persistensi Laba dengan Book Tax Defferences sebagai Variabel Moderating, Jurnal Ekonomi dan Teknik Informatika, $9(1), 58-67$.

Susilo, T.P., \& Anggraeni, B.M. (2015). Analisis Pengaruh Volatilitas Arus Kas, Tingkat Utang, Siklus Operasi dan Ukuran Perusahaan terhadap Persistensi Laba. Media Riset Akuntansi, 6(1), 1-21.

Tuffahati, F.L., Gurendrawati, E., \& Muliasari, I. (2020). Faktor-faktor yang Mempengaruhi Persistensi Laba. Jurnal Akuntansi, Perpajakan dan Auditing, 1(2), 145-159.

Widiatmoko, J., \& Indarti, K.M.G. (2019). Book Tax Differences, Operating Cash Flow, Leverage and Earning Persistence in Indonesia Manufacturing Companies. Jurnal Dinamika Akuntansi, 11(2), 151-159. https://doi.org/10.15294/jda.v11i2.20481.

Yanti. (2017). The Effects of Operating Cash Flow, Sales Volatility, and Leverage on Earnings' Persistence. International Journal of Economic Perspectives, 11(1), 1535-1544. https://search. proquest.com/docview/1964554926?accountid=17242. 